\title{
PENGGUNAAN LINDI HITAM SEBAGAI BAHAN PELUNAK DALAM KOMPON KARET ALAM
}

\author{
Use of Black Liquor as Plasticizer in Natural Rubber Compounds
}

\author{
Adi CIFRIADI
}

Pusat Penelitian Karet

Jl. Salak No.1 Bogor 16151

Email : cifriadi9748@gmail.com

Diterima tanggal 15 Februari 2013 / disetujui tanggal 25 Mei 2013

\begin{abstract}
Physical properties and curing characteristics of natural rubber compound containing black liquor and FTIR Spectrometry analysis of black liquor were studied to evaluate its suitability as plasticizer. Aromatic oil was used as a reference plasticizer. The plasticizer of black liquor was made based on a type of basic material and the number of its solid content. The result of characterization on black liquor by FTIR spectrometry concluded that the functional groups attached to the molecule of black liquor and the result of interpretation FTIR spectra of black liquor indicated that the black liquor consists of aromatic rings in structure, $-\mathrm{OH},-\mathrm{C}-\mathrm{O}$, and $\mathrm{C}=\mathrm{O}$ groups. Base on the curing characteristics, rubber compound containing black liquor processed as plasticizer with or without treatment of $\mathrm{NH}_{4} \mathrm{OH}$ and $\mathrm{NaOH}$ had optimum cure time $\left(t_{90}\right)$ and faster scorch time $\left(t_{2}\right)$ compared with the reference plasticizer (minarex). Physical properties of vulcanizate showed that vulcanizate containing black liquor processed as plasticizer without treatment of basic material and containing $60 \%$ of solid content had similar performance to vulcanizate containing reference plasticizer.
\end{abstract}

Key words: Black liquor, plasticizer, natural rubber compound, vulcanizate

\footnotetext{
Abstrak

Sifat fisika vulkanisat dan karakteristik kematangan kompon karet alam yang mengandung lindi hitam dan analisis spektrometri FTIR dari lindi hitam telah dikaji untuk mengevaluasi penggunaan lindi hitam sebagai bahan pelunak. Bahan
}

pelunak jenis aromatik digunakan sebagai bahan pelunak kontrol. Bahan pelunak dari lindi hitam dibuat dengan perlakuan berdasarkan jenis bahan pembasa yang ditambahkan pada lindi hitam serta jumlah kadar padatannya. Hasil pengujian spektrometri FTIR dapat menyimpulkan gugus fungsi yang terikat pada struktur molekul lindi hitam dan hasil interpretasi spektra FTIR menunjukkan bahwa lindi hitam mengandung senyawa cincin aromatik pada struktur molekulnya dan mengandung gugus fungsi $-\mathrm{OH},-\mathrm{C}-\mathrm{O}$, serta $-\mathrm{C}=\mathrm{O}$. Berdasarkan hasil pengujian karakteristik kematangan kompon terlihat bahwa kompon karet yang mengandung bahan pelunak lindi hitam tanpa perlakuan ataupun dengan perlakukan penambahan bahan pembasa $\mathrm{NH}_{4} \mathrm{OH}$ dan $\mathrm{NaOH}$ memiliki waktu masak optimum $\left(\mathrm{t}_{90}\right)$ dan waktu penundaan/scorch $\left(\mathrm{ts}_{2}\right)$ yang lebih cepat dari pada kompon karet yang mengandung bahan pelunak kontrol (minarex). Hasil pengujian sifat fisika vulkanisat menunjukkan bahwa vulkanisat yang mengandung lindi hitam tanpa perlakuan penambahan bahan pembasa dengan kadar padatan sebesar $60 \%$ memiliki kinerja yang setara dengan vulkanisat yang mengandung bahan pelunak kontrol.

Katakunci: Lindi hitam, bahan pelunak, kompon karet alam, vulkanisat

\section{PENDAHULUAN}

Produk barang jadi karet sangat beragam, mulai dari produk untuk penggunaan umum sampai produk penggunaan khusus. Berdasarkan proses pembuatannya, produk barang jadi karet 
digolongkan menjadi dua bagian, yaitu barang jadi karet padat dan lateks. Proses pembuatan barang jadi karet padat dilakukan dalam fase padat, sedangkan proses pembuatan produk barang jadi lateks dilakukan dalam fase cair. Contoh produk barang jadi karet padat adalah ban kendaraan, selang karet (rubber hose), conveyor belt, bantalan mesin, dan seal sedangkan produk barang jadi lateks misalnya balon, gelang karet, benang karet, dan sarung tangan.

Umumnya, sekitar $60 \%$ produk barang jadi karet dalam negeri berupa ban kendaraan bermotor, dalam pemrosesannya digunakan bahan karet dan bahan kimia karet seperti bahan pengisi, bahan pelunak, bahan pemvulkanisasi, bahan pencepat, bahan pengaktif, dan bahan anti degradasi. Dalam pembuatan ban kendaraan, selain karet, bahan kimia berupa bahan pengisi dan bahan pelunak merupakan bahan yang memiliki persentase pemakaian paling dominan. Bahan pelunak digunakan sekitar $8-20 \%$ dalam pembuatan ban kendaraan. Berdasarkan data BPS 2010, total ekspor Indonesia untuk semua jenis ban tercatat sebanyak 4,2 juta ton atau sekitar 50 juta unit. Apabila dalam pembuatan ban digunakan bahan pelunak (plasticizer) sebanyak 15\% maka kebutuhan bahan pelunak untuk industri ban kendaraan adalah sekitar 630.000 ton yang semuanya berasal dari bahan pelunak sintetis yang diperoleh dari pengolahan minyak bumi.

Penelitian bahan pelunak alami diperlukan untuk mensubtitusi bahan pelunak sintetis yang berasal dari pengolahan minyak bumi seperti bahan pelunak jenis parafinik, aromatik, naftenik dan dioktilptalat. Lindi hitam merupakan salah satu hasil dari pirolisis limbah biomassa dan sampai saat ini belum dimanfaatkan sebagai bahan yang bersifat komersial. Dalam lindi hitam terdapat dua komponen utama yakni air dan lignin. Lignin dalam lindi hitam terdapat sekitar $15-20 \%$ yang tersusun atas unit-unit fenil propana. Berdasarkan struktur molekulnya, lignin merupakan makromolekul yang memiliki berat molekul lebih dari 15.000 (McCrady, 1991) dan mengandung banyak senyawa aromatik (Vanholme et al., 2010). Penelitian yang telah dilakukan Honggokusumo dan Bahar (1998) menunjukkan bahwa lignin yang diperoleh dari limbah pulp kertas kraft dapat digunakan sebagai bahan pelunak kompon karet alam dengan sistem vulkanisasi semi efisien dan dapat meningkatkan ketahanan usang terhadap panas. Oleh karena itu, dalam penelitian ini akan dikaji peluang pemanfaatan lindi hitam dari pirolisis limbah biomassa sebagai bahan pelunak alami untuk mensubtitusi bahan pelunak sintetis khususnya bahan pelunak jenis aromatik.

\section{BAHAN DAN METODE}

Pada penelitian ini dilakukan kajian kualitas lindi hitam sebagai bahan pelunak dalam pembuatan barang jadi karet dengan mempelajari karakteristik pematangan kompon dan sifat fisika barang jadi karet yang mengandung lindi hitam sebagai bahan pelunak. Bahan-bahan kimia yang dipakai dalam penelitian ini adalah : lindi hitam dari PT Global Deorub Industry, $\mathrm{NaOH}, \mathrm{NH}_{4} \mathrm{OH}$, karet alam, $\mathrm{ZnO}$, asam stearat, sulfur, n-Cycloheksil 2-Benzotiazol Sulphenamide (CBS), kaolin, dan minyak aromatikjenis minarex.

Pembuatan bahan pelunak dari lindi hitam, pembuatan kompon karet alam, pengujian karakteristik kematangan kompon karet, dan pengujian sifat fisika vulkanisat dilakukan di Pusat Penelitian Karet. Penelitian dilakukan dari bulan Januari 2011 sampai bulan Oktober 2012.

\section{Penyiapan Lindi Hitam sebagai Bahan Pelunak}

Sebanyak 600 g lindi hitam dimasukkan ke dalam gelas kimia tanpa bahan pembasa atau ditambahkan bahan pembasa. Selanjutnya lindi hitam dipekatkan dengan cara diaduk dan dipanaskan pada suhu $105^{\circ} \mathrm{C}$. Lindi hitam kemudian didinginkan pada suhu ruang dan selanjutkan dapat digunakan untuk sampel sebagai bahan pelunak. Dalam penelitian ini dilakukan dua perlakuan pada lindi hitam yaitu : kadar padatan dan jenis pembasaan lindi hitam. Terdapat tiga jenis lindi hitam, yaitu : lindi hitam yang ditambahkan $\mathrm{NaOH}$, $\mathrm{NH}_{4} \mathrm{OH}$, dan tanpa penambahan bahan pembasa. Untuk perlakuan lindi hitam berdasarkan pada kadar padatan sampel 
yang terdiri atas tiga jenis, yaitu : 60\%; 65\%; dan $70 \%$ kadar padatan.

\section{Pengujian Lindi Hitam}

Pengujian lindi hitam yang dilakukan adalah kadar abu, kadar zat menguap, kadar padatan, $\mathrm{pH}$, dan spektrometri FTIR.

\section{Pembuatan Kompon Karet}

Sampel lindi hitam yang telah diketahui kadar zat menguapnya ditimbang. Karet alam dan bahan kimia karet termasuk sampel bahan pelunak lindi hitam dicampurkan di dalam mesin giling dua rol terbuka untuk membuat kompon karet. Formulasi bahan sesuai dengan Tabel 1 . Terdapat 9 (sembilan) jenis lindi hitam, yaitu: lindi hitam tanpa penambahan bahan pembasa (60; 65; 70\% kadar padatan), lindi hitam yang ditambahkan $\mathrm{NaOH}(60 \%$; 65\%; $70 \%$ kadar padatan), dan lindi hitam yang ditambahkan $\mathrm{NH}_{4} \mathrm{OH}$ (60\%; 65\%; 70\% kadar padatan).

\section{Pengujian Karakteristik Kematangan Kompon dan Sifat Fisika Bahan}

Karakteristik kematangan kompon karet ditentukan dengan alat Rheometer dan sifat fisika bahan yang diuji meliputi :

Tabel 1. Formula bahan untuk pembuatan kompon karet

Table 1. Formula for rubber compound preparation

\begin{tabular}{lcc}
\hline \multicolumn{1}{c}{$\begin{array}{c}\text { Bahan } \\
\text { Material }\end{array}$} & $\begin{array}{c}\text { Lindi hitam } \\
\text { Black liquor }\end{array}$ & Minarex \\
\hline Karet alam (natural rubber) & 100 & 100 \\
ZnO & 4 & 4 \\
Asam stearat (stearat acid) & 3,5 & 3,5 \\
Kaolin & 45 & 45 \\
Bahan pelunak (Plasticizer): & & \\
- Lindi hitam (black liquor) & 4 & - \\
- Minarex & - & 4 \\
TMQ & 1 & 1 \\
CBS & 0,45 & 0,45 \\
Sulfur (Sulphur) & 2,5 & 2,5 \\
\hline
\end{tabular}

kekerasan, kuat tarik, perpanjangan putus, ketahanan sobek, densitas, ketahanan abrasi, kepegasan pantul, ketahanan retak lentur, dan ketahanan ozon.

\section{HASIL DAN PEMBAHASAN}

\section{Pengujian Lindi Hitam}

Lindi hitam yang digunakan dalam penelitian ini berasal dari residu pirolisis cangkang kelapa sawit. Berdasarkan hasil pengujian seperti yang ditunjukkan dalam Tabel 2 bahwa lindi hitam yang digunakan mengandung kadar padatan sebanyak $21,64 \%$. Kadar padatan ini mengandung lignin yang apabila bercampur dengan karet diduga dapat menyebabkan karet menjadi lebih lunak dengan kata lain lignin dalam lindi hitam dapat berfungsi sebagai bahan pelunak. Berdasarkan struktur molekulnya, lignin merupakan makromolekul yang memiliki berat molekul lebih dari 15000 (McCrady, 1991) dan mengandung banyak senyawa aromatik (Vanholme et al., 2010) seperti yang ditunjukkan pada Gambar 1, sehingga memiliki peluang digunakan sebagai bahan pelunak karet.

Pengujian spektrometri FTIR dilakukan untuk mengetahui gugus fungsional yang dimiliki lindi hitam. Gugus fungsional ini, berdasarkan sifat bahan secara mikrostruktural akan mempengaruhi kesesuaian penggunaan bahan pada saat diaplikasikan sebagai bahan pelunak untuk barang jadi karet, diantaranya untuk menentukan jenis bahan pelunak dari golongan senyawa parafinik, aromatik, atau naftenik. Berikut ini pada Gambar 2

Tabel 2. Sifat-sifat lindi hitam

Table 2. Properties of black liquor

\begin{tabular}{lc}
\hline \multicolumn{1}{c}{$\quad \begin{array}{c}\text { Karakteristik } \\
\text { Characteristics }\end{array}$} & $\begin{array}{c}\text { Nilai } \\
\text { values }\end{array}$ \\
\hline $\begin{array}{l}\text { Kadar padatan } \\
\text { Solid content }\end{array}$ & $21,64 \%$ \\
Kadar zat menguap \\
$\begin{array}{l}\text { Volatile matter content } \\
\text { pH }\end{array}$ & $78,36 \%$ \\
Kadar abu & 2 \\
Ash content & $0,03 \%$ \\
\hline
\end{tabular}




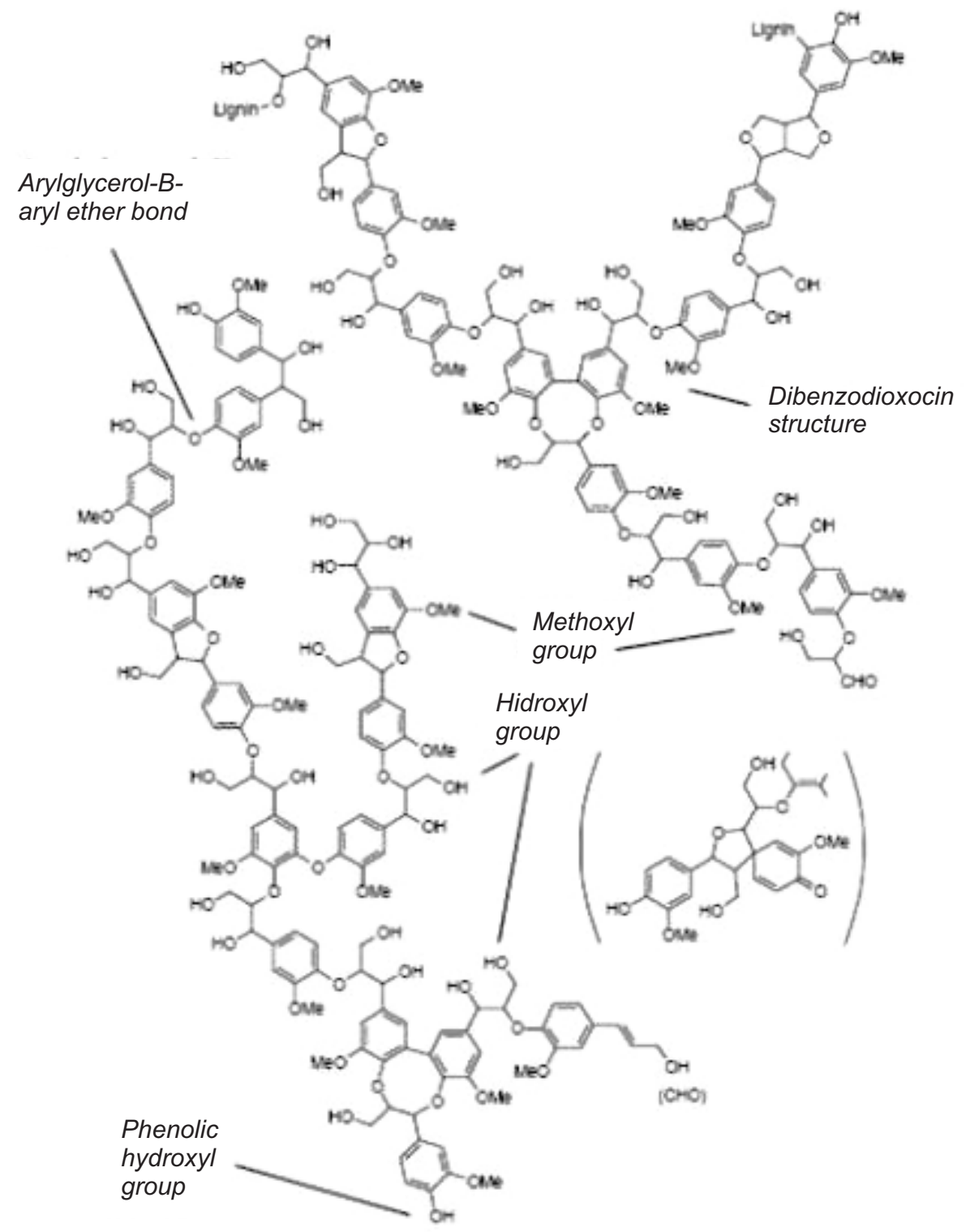

Sumber (Source) : Brunow, 1998

Gambar 1. Struktur molekul lignin

Figure 1. Structure of lignin molecular

ditunjukkan spektra FTIR dari lindi hitam mentah dan lindi hitam setelah diproses untuk digunakan sebagai bahan pelunak.

Berdasarkan spektra FTIR yang diperoleh pada Gambar 2 dapat diinterpretasikan jenis gugus fungsional yang dimiliki bahan lindi hitam mentah dan setelah perlakuan yang dirangkum dalam Tabel 3.
Hasil interpretasi spektra FTIR yang terangkum dalam Tabel 3 dapat diperoleh informasi bahwa lindi hitam mentah dan setelah perlakuan memiliki puncak-puncak spektra FTIR yang sebagian besar sama. Hal ini menunjukkan bahwa proses perlakuan pemanasan (penguapan zat menguap) tidak mengakibatkan perubahan struktur molekul lindi hitam, seperti terjadinya oksidasi lindi hitam. Proses perlakuan 


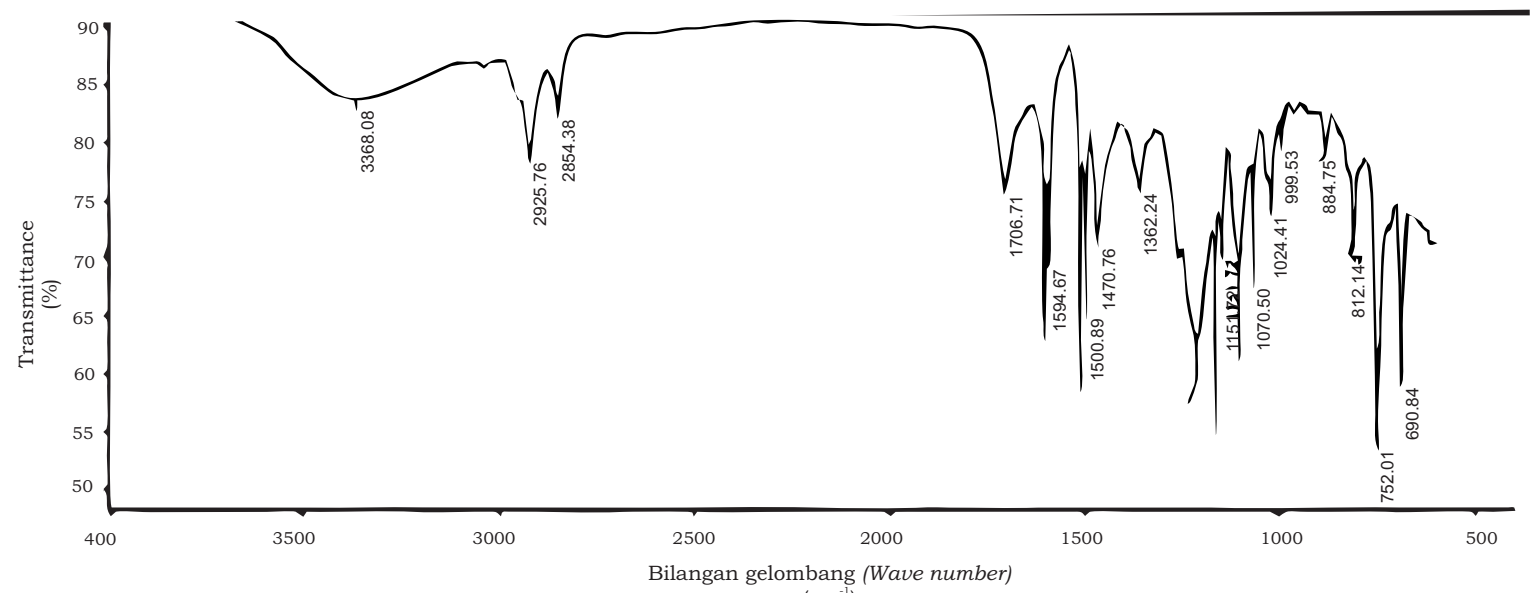

$$
\left(\mathrm{cm}^{-1}\right)
$$

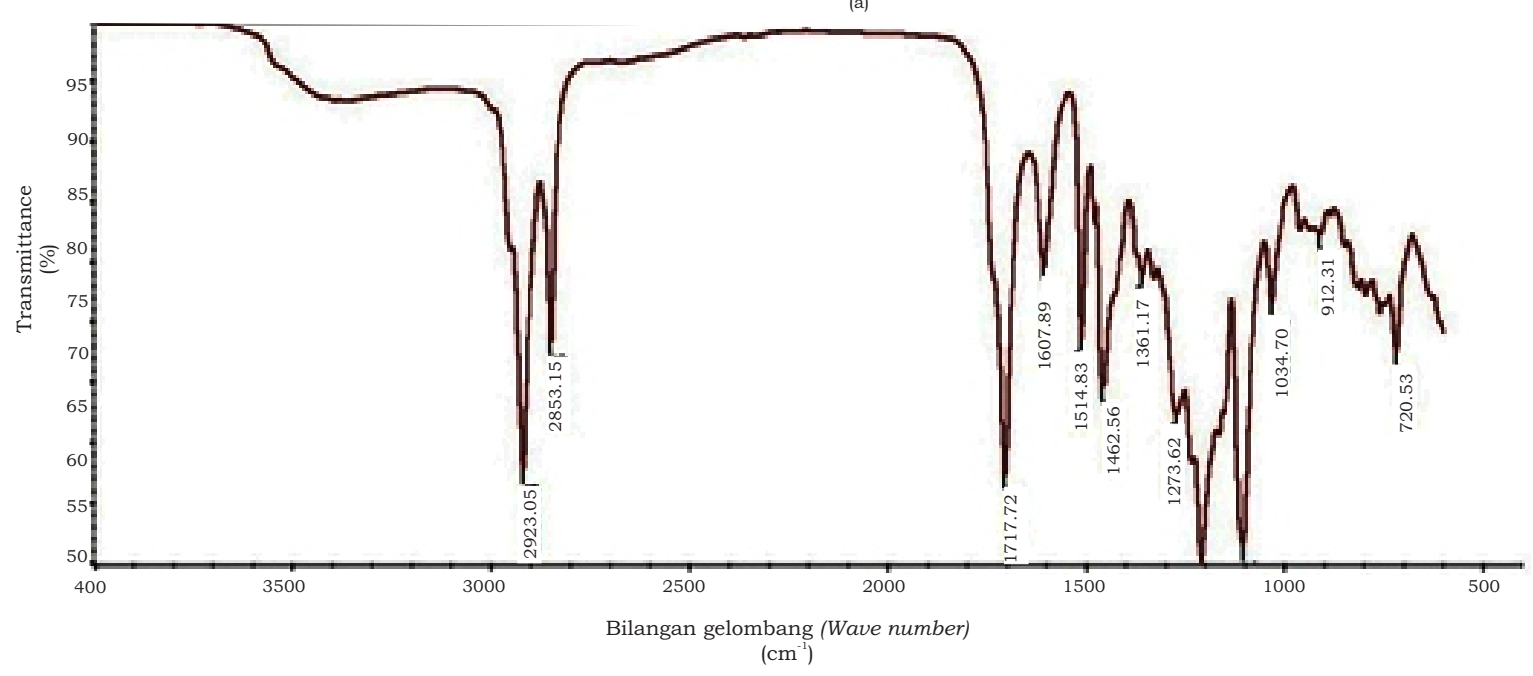

(b)

Gambar 2. Spektra FTIR dari (a) lindi hitam mentah, dan (b) lindi hitam setelah perlakuan Figure 2. FTIR spectra of (a) black liquor, and (b) black liquor after treatment

Tabel 3. Interpretasi spektra FTIR

Table 3. Interpretation of FTIR spectra

\begin{tabular}{|c|c|c|}
\hline $\begin{array}{l}\text { Contoh } \\
\text { Samples }\end{array}$ & $\begin{array}{c}\text { Bilangan gelombang } \\
\text { Wavenumbers } \\
\mathrm{cm}^{-1}\end{array}$ & $\begin{array}{l}\text { Interpretasi } \\
\text { Interpretation }\end{array}$ \\
\hline $\begin{array}{c}\text { Lindi hitam } \\
\text { mentah } \\
\text { Raw black liquor }\end{array}$ & $\begin{array}{l}3368,08 \\
2925,76 \text { dan } 2854,38 \\
1706,71 \\
1605,51 \text { dan } 1594,67 \\
1470,76 \\
1362,24 \\
1214,80 \\
1070,50 \text { dan } 1107,20\end{array}$ & $\begin{array}{l}\text { Vibrasi ulur }-\mathrm{OH} \\
\text { Vibrasi ulur } \mathrm{C}-\mathrm{H} \text { dari metilen }\left(-\mathrm{CH}_{2}-\right) \\
\text { Gugus fungsional keton } \\
\text { Vibrasi ulur cincin aromatik } \mathrm{C}=\mathrm{C}-\mathrm{C} \\
\text { Vibrasi tekuk } \mathrm{C}-\mathrm{H} \text { dari metilen }\left(-\mathrm{CH}_{2}-\right) \\
\text { Vibrasi tekuk }-\mathrm{OH} \text { dari fenol } \\
\text { Vibrasi ulur } \mathrm{C}-\mathrm{O} \text { dari fenol } \\
\text { Vibrasi ulur } \mathrm{C}-\mathrm{O} \text {, eter tersubtitusi alkil (C-O-C) }\end{array}$ \\
\hline $\begin{array}{l}\text { Lindi hitam } \\
\text { setelah perlakuan } \\
\text { Black liqour after } \\
\text { treatment }\end{array}$ & $\begin{array}{l}\sim 3300 \\
2923,05 \text { dan } 2853,15 \\
1707,72 \\
1607,89 \\
1462,56 \\
1361,77 \\
\sim 1200 \\
\sim 1100 \\
\end{array}$ & $\begin{array}{l}\text { Vibrasi ulur }-\mathrm{OH} \\
\text { Vibrasi ulur } \mathrm{C}-\mathrm{H} \text { dari metilen }\left(-\mathrm{CH}_{2}-\right) \\
\text { Gugus fungsional keton } \\
\text { Vibrasi ulur cincin aromatik } \mathrm{C}=\mathrm{C}-\mathrm{C} \\
\text { Vibrasi tekuk } \mathrm{C}-\mathrm{H} \text { dari metilen }\left(-\mathrm{CH}_{2}-\right) \\
\text { Vibrasi tekuk }-\mathrm{OH} \text { dari fenol } \\
\text { Vibrasi ulur } \mathrm{C}-\mathrm{O} \text { dari fenol } \\
\text { Vibrasi ulur } \mathrm{C}-\mathrm{O} \text {, eter tersubtitusi alkil (C-O-C) }\end{array}$ \\
\hline
\end{tabular}


penguapan zat menguap hanya mengakibatkan perubahan fisik bahan seperti viskositas semakin meningkat karena proses tersebut mengakibatkan jumlah padatan semakin meningkat disebabkan hilangnya air dan bahan mudah menguap akibat proses pemanasan pada $105^{\circ} \mathrm{C}$. Hal ini didukung dari spekta FTIR pada bilangan gelombang sekitar $3400 \mathrm{~cm}^{-1}$ pada lindi hitam setelah perlakuan memiliki luas area serapan yang lebih kecil.

Berdasarkan sifat fisiknya, lindi hitam (tar) yang diperoleh dari hasil pirolisis limbah biomassa memiliki warna hitam dan umumnya terdiri dari dua komponen utama yakni air dan lignin. Lignin dalam lindi hitam ini terdapat sekitar 15 - 20\% yang tersusun atas unit-unit fenil propana.

Dalam penelitian ini dilakukan penambahan bahan pembasa seperti $\mathrm{NaOH}$ dan $\mathrm{NH}_{4} \mathrm{OH}$ untuk mengurangi sifat keasaman dari lindi hitam. Dalam pembuatan kompon karet, bahan kimia yang bersifat asam akan mempengaruhi karakteristik vulkanisasi sehingga lindi hitam perlu diperlakukan pengurangan sifat keasamannya dengan penambahan bahan pembasa.
Disamping penambahan bahan pembasa, lindi hitam mentah masih mengandung air sehingga air harus dihilangkan dari lindi hitam terlebih dahulu karena apabila digunakan sebagai bahan kimia kompon karet, adanya air dapat mengganggu sifat akhir produk karet yaitu menghasilkan gelembung-gelembung udara yang terperangkap dalam produk karet dan hal ini merupakan salah satu cacat dalam produk karet. Dalam penelitian ini, untuk menghilangkan air dalam lindi hitam dilakukan proses penguapan air melalui pemanasan lindi hitam pada suhu $105^{\circ} \mathrm{C}$. Pada Tabel 4 disajikan hasil pengujian kadar zat menguap dan abu beberapa contoh lindi hitam dengan perbedaan perlakuan.

\section{Karakteristik Kematangan Kompon}

Proses vulkanisasi kompon karet merupakan suatu reaksi kimiawi yang bersifat tidak dapat balik (irreversible) melalui pembentukan ikatan silang bahan pemvulkanisasi pada rantai molekul karet. Hasil pengujian karakteristik vulkanisasi juga memberikan informasi tentang derajat/tingkat vulkanisasi yang terjadi pada kompon karet. Derajat vulkanisasi

Tabel 4. Kadar zat menguap dan abu pada contoh lindi hitam dengan perbedaan perlakuan Teble 4. Volatile matter and ash contents of black liquor in different treatments

\begin{tabular}{|c|c|c|}
\hline $\begin{array}{l}\text { Lindi hitam } \\
\text { Black liquor }\end{array}$ & $\begin{array}{c}\text { Kadar zat } \\
\text { menguap } \\
\text { Volatile matter } \\
\text { content } \\
\text { (\%) }\end{array}$ & $\begin{array}{c}\text { Kadar abu } \\
\text { Ash content } \\
\text { (\%) }\end{array}$ \\
\hline $\begin{array}{l}\text { Lindi hitam mengandung kadar padatan } 60 \% \text { (LA } 1) \\
\text { Black liquor containing } 60 \% \text { of solid content (LA 1) }\end{array}$ & 40 & 1,24 \\
\hline $\begin{array}{l}\text { Lindi hitam mengandung kadar padatan } 65 \% \text { (LA2) } \\
\text { Black liquor containing } 65 \% \text { of solid content (LA2) }\end{array}$ & 35 & 1,48 \\
\hline $\begin{array}{l}\text { Lindi hitam mengandung kadar padatan } 70 \% \text { (LA3) } \\
\text { Black liquor containing } 70 \% \text { of solid content (LA3) }\end{array}$ & 30 & 1,69 \\
\hline $\begin{array}{l}\text { Lindi hitam mengandung kadar padatan } 60 \% \text { dan } \mathrm{NaOH} \text { (LB } 1) \\
\text { Black liquor containing } 60 \% \text { of solid content and } \mathrm{NaOH}(L B 1)\end{array}$ & 40 & 6,03 \\
\hline $\begin{array}{l}\text { Lindi hitam mengandung kadar padatan } 65 \% \text { dan } \mathrm{NaOH}(\mathrm{LB} 2) \\
\text { Black liquor containing } 65 \% \text { of solid content and } \mathrm{NaOH}(\mathrm{LB} 2)\end{array}$ & 35 & 6,70 \\
\hline $\begin{array}{l}\text { Lindi hitam mengandung kadar padatan } 70 \% \text { dan } \mathrm{NaOH} \text { (LB3) } \\
\text { Black liquor containing } 70 \% \text { of solid content and } \mathrm{NaOH} \text { (LB3) }\end{array}$ & 30 & 7,03 \\
\hline $\begin{array}{l}\text { Lindi hitam mengandung kadar padatan } 60 \% \text { dan } \mathrm{NH}_{4} \mathrm{OH}(\mathrm{LC} 1) \\
\text { Black liquor containing } 60 \% \text { of solid content and } \mathrm{NH}_{4} \mathrm{OH} \text { (LC1) }\end{array}$ & 40 & 0,33 \\
\hline $\begin{array}{l}\text { Lindi hitam mengandung kadar padatan } 65 \% \text { dan } \mathrm{NH}_{4} \mathrm{OH} \text { (LC2) } \\
\text { Black liquor containing } 65 \% \text { of solid content and } \mathrm{NH}_{4} \mathrm{OH} \text { (LC2) }\end{array}$ & 35 & 0,36 \\
\hline $\begin{array}{l}\text { Lindi hitam mengandung kadar padatan } 70 \% \text { dan } \mathrm{NH}_{4} \mathrm{OH} \text { (LC3) } \\
\text { Black liquor containing } 70 \% \text { of solid content and } \mathrm{NH}_{4} \mathrm{OH} \text { (LC3) }\end{array}$ & 30 & 2,69 \\
\hline
\end{tabular}


dapat diperkirakan melalui selisih antara modulus torsi maksimum (MHR) dengan modulus torsi minimum (ML) ataupun dari nilai modulus torsi optimum $\left(\mathrm{M}_{90}\right)$. Derajat vulkanisasi ini menunjukkan derajat ikatan silang yang terbentuk pada molekul karet, semakin tinggi nilai derajat vulkanisasi maka semakin tinggi pula derajat ikatan silang yang terbentuk. Nilai derajat vulkanisasi ini juga dapat mempengaruhi sifat fisik vulkanisat, seperti : kuat tarik, kekerasan, modulus dll. Hasil penelitian yang ditunjukkan dalam Tabel 5, bahwa kompon karet yang mengandung bahan pelunak lindi hitam tanpa perlakuan (LA1, LA2, LA3) memiliki nilai modulus torsi optimum hampir sama dengan kompon karet yang mengandung bahan pelunak lindi hitam dengan perlakuan penambahan bahan $\mathrm{NaOH}$ (LB1, LB2, LB3), sedangkan kompon karet yang mengandung bahan bahan pelunak minarex (M) memiliki nilai modulus torsi optimum hampir sama dengan kompon karet yang mengandung bahan pelunak lindi hitam dengan perlakuan penambahan bahan $\mathrm{NH}_{4} \mathrm{OH}$ (LC1, LC2, dan LC3). Nilai modulus torsi optimum yang tertinggi sebesar $10,04 \mathrm{~kg}-\mathrm{cm}$

Tabel 5. Karakteristik kematangan kompon karet dengan bahan pelunak dari lindi hitam Table 5. Curing characteristic of rubber compound with black liquor plasticizer

\begin{tabular}{|c|c|c|c|c|c|}
\hline \multirow[b]{2}{*}{$\begin{array}{l}\text { Kandungan Kompon karet } \\
\text { Contents of Rubber compound }\end{array}$} & \multicolumn{5}{|c|}{$\begin{array}{l}\text { Karakteristik kematangan } \\
\text { Curing characteristics }\end{array}$} \\
\hline & $\begin{array}{l}\text { Torsi max } \\
\text { (MH) } \\
(\mathrm{kg}-\mathrm{cm})\end{array}$ & $\begin{array}{l}\text { Torsi min } \\
\text { (ML) } \\
(\mathrm{kg}-\mathrm{cm})\end{array}$ & $\begin{array}{l}\text { MHML, } \\
(\mathrm{kg}-\mathrm{cm})\end{array}$ & $\begin{array}{l}\text { Waktu optimum } \\
\text { Optimum time } \\
\left(\mathrm{t}_{90}\right) \\
\text { (min, sec) }\end{array}$ & $\begin{array}{c}\text { Waktu } \\
\text { penundaan/pra } \\
\text { vulkanisasi } \\
\text { Scorch time } \\
\left(\mathrm{ts}_{2}\right) \\
(\mathrm{min}, \mathrm{sec}) \\
\end{array}$ \\
\hline $\begin{array}{l}\text { Lindi hitam mengandung kadar } \\
\text { padatan } 60 \% \text { (LA1) } \\
\text { Black liquor containing } 60 \% \text { of solid } \\
\text { content (LA1) }\end{array}$ & 8,02 & 0,14 & 7,88 & 13,48 & 5,23 \\
\hline $\begin{array}{l}\text { Lindi hitam mengandung kadar } \\
\text { padatan } 65 \% \text { (LA2) } \\
\text { Black liquor containing } 65 \% \text { of solid } \\
\text { content (LA2) }\end{array}$ & 7,98 & 0,17 & 7,81 & 13,26 & 5,05 \\
\hline $\begin{array}{l}\text { Lindi hitam mengandung kadar } \\
\text { padatan } 70 \% \text { (LA3) } \\
\text { Black liquor containing } 70 \% \text { of solid } \\
\text { content (LA3) }\end{array}$ & 8,05 & 0,16 & 7,89 & 13,49 & 5,04 \\
\hline $\begin{array}{l}\text { Lindi hitam mengandung kadar } \\
\text { padatan } 60 \% \text { dan } \mathrm{NaOH} \text { (LB1) } \\
\text { Black liquor containing } 60 \% \text { of solid } \\
\text { content and } \mathrm{NaOH} \text { (LB1) }\end{array}$ & 7,68 & 0,10 & 7,58 & 11,06 & 4,12 \\
\hline $\begin{array}{l}\text { Lindi hitam mengandung kadar } \\
\text { padatan } 65 \% \text { dan } \mathrm{NaOH} \text { (LB2) } \\
\text { Black liquor containing } 65 \% \text { of solid } \\
\text { content and NaOH (LB2) }\end{array}$ & 7,57 & 0,18 & 7,39 & 11,21 & 4,07 \\
\hline $\begin{array}{l}\text { Lindi hitam mengandung kadar } \\
\text { padatan } 70 \% \text { dan } \mathrm{NaOH} \text { (LB3) } \\
\text { Black liquor containing } 70 \% \text { of solid } \\
\text { content and } \mathrm{NaOH} \text { (LB3) }\end{array}$ & 9,26 & 0,26 & 9,00 & 11,04 & 3,36 \\
\hline $\begin{array}{l}\text { Lindi hitam mengandung kadar } \\
\text { padatan } 60 \% \text { dan } \mathrm{NH}_{4} \mathrm{OH} \text { (LC1) } \\
\text { Black liquor containing } 60 \% \text { of solid } \\
\text { content and } \mathrm{NH}_{4} \mathrm{OH}(\mathrm{LC} 1)\end{array}$ & 9,23 & 0,27 & 8,96 & 10,06 & 3,36 \\
\hline $\begin{array}{l}\text { Lindi hitam mengandung kadar } \\
\text { padatan } 65 \% \text { dan } \mathrm{NH}_{4} \mathrm{OH} \text { (LC2) } \\
\text { Black liquor containing } 65 \% \text { of solid } \\
\text { content and } \mathrm{NH}_{4} \mathrm{OH}(\mathrm{LC} 2)\end{array}$ & 10,35 & 0,21 & 10,04 & 9,54 & 3,03 \\
\hline $\begin{array}{l}\text { Lindi hitam mengandung kadar } \\
\text { padatan } 70 \% \text { dan } \mathrm{NH}_{4} \mathrm{OH} \text { (LC3) } \\
\text { Black liquor containing } 70 \% \text { of solid } \\
\text { content and } \mathrm{NH}_{4} \mathrm{OH}(\mathrm{LC} 3)\end{array}$ & 9,69 & 0,14 & 9,55 & 10,00 & 3,23 \\
\hline $\begin{array}{l}\text { Minarex }(\mathrm{M}) \\
\text { Minarex (control) }\end{array}$ & 6,98 & 0,16 & 6,82 & 15,59 & 6,09 \\
\hline
\end{tabular}




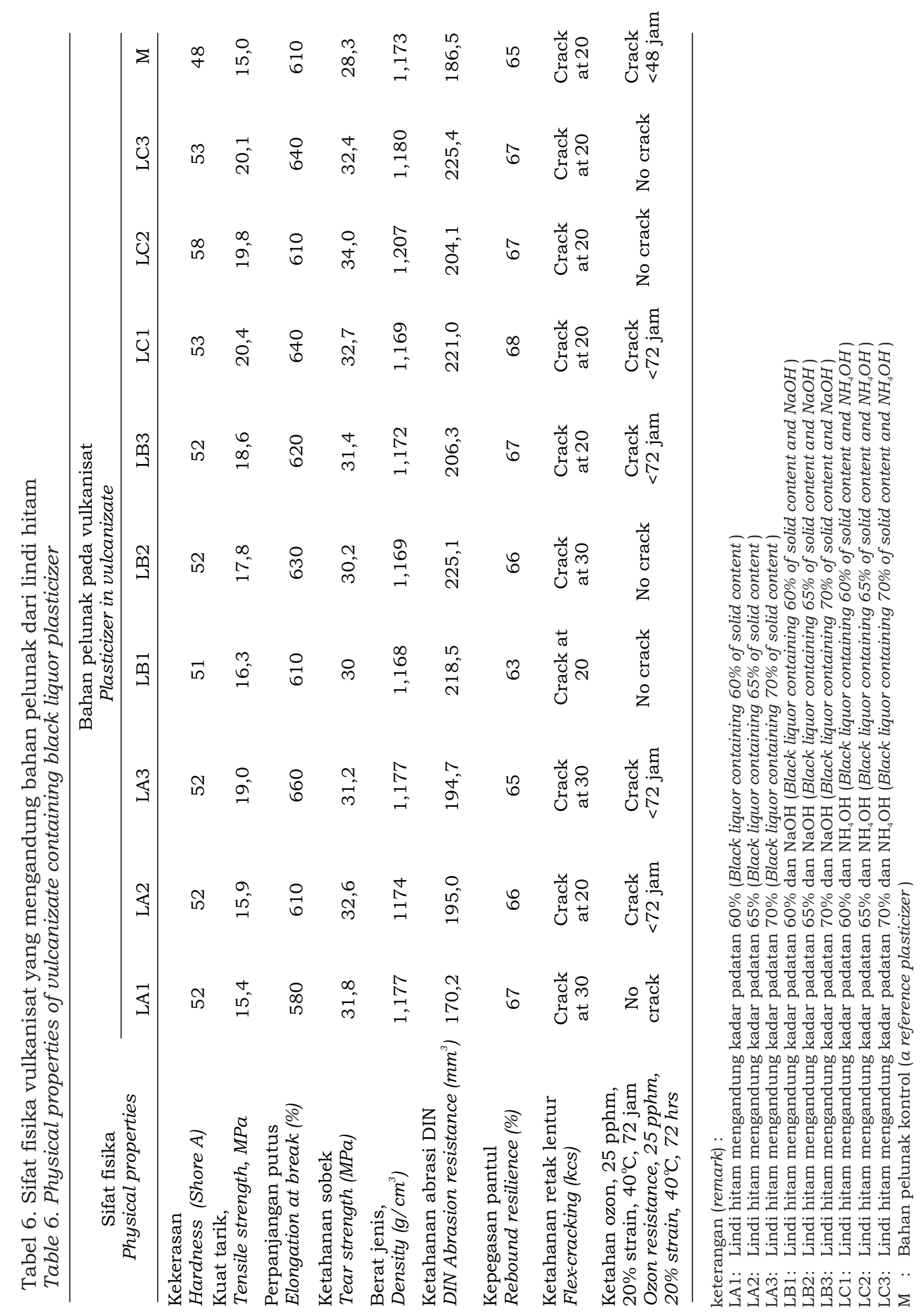


dihasilkan dari kompon karet yang mengandung bahan pelunak lindi hitam dengan perlakuan penambahan bahan $\mathrm{NH}_{4} \mathrm{OH}$ dengan kadar padatan $65 \%$, sedangkan modulus torsi optimum terendah sebesar 6,82 kg-cm dihasilkan dari kompon karet yang mengandung bahan pelunak pembanding/ kontrol (minarex).

Karakteristik vulkanisasi lain yang penting dalam pemrosesan barang jadi karet adalah waktu masak optimum $\left(\mathrm{t}_{90}\right)$ dan waktu scorch $\left(\mathrm{ts}_{2}\right)$. Berdasarkan hasil pengujian yang ditunjukkan pada Tabel 5 dapat diperoleh informasi bahwa waktu masak optimum dan waktu scorch kompon karet yang mengandung bahan pelunak lindi hitam tanpa perlakuan ataupun dengan perlakuan penambahan bahan $\mathrm{NaOH}$ dan $\mathrm{NH}_{4} \mathrm{OH}$ lebih cepat daripada kompon karet yang mengandung bahan pelunak kontrol (minarex). Waktu masak optimum rata-rata dari kompon karet yang mengadung bahan pelunak lindi hitam tanpa perlakuan, dengan perlakuan penambahan bahan $\mathrm{NaOH}$ dan $\mathrm{NH}_{4} \mathrm{OH}$ berturut-turut sebesar 13 menit, 11 menit, dan 10 menit, sedangkan kompon karet yang mengandung bahan minarex memiliki waktu masak optimum sebesar 16 menit.

\section{Sifat Fisika Barang Jadi Karet}

Berdasarkan hasil pengujian sifat fisik vulkanisat yang terangkum dalam Tabel 6 , sifat-sifat fisika vulkanisat (kekerasan, kuat tarik, perpanjangan putus, ketahanan sobek, berat jenis, kepegasan pantul, ketahanan retak-lentur, ketahanan kikis, dan ketahanan ozon) yang mengandung bahan pelunak lindi hitam dengan perlakuan penambahan bahan pembasa ataupun tanpa perlakuan memiliki hasil yang hampir setara dengan sifat fisika vulkanisat yang mengandung bahan pelunak kontrol (minarex), bahkan untuk beberapa sifat fisika vulkanisat yang mengandung bahan pelunak lindi hitam lebih baik, seperti : kuat tarik, ketahanan sobek, ketahanan retak-lentur, dan ketahanan ozon.

Hasil pengujian sifat fisika vulkanisat dalam Tabel 6 memberikan informasi bahwa vulkanisat yang mengandung bahan pelunak lindi hitam dengan kadar padatan sebesar $70 \%$ memiliki sifat kekerasan dan kuat tarik lebih tinggi daripada vulkanisat yang mengandung bahan pelunak lindi hitam dengan kadar padatan sebesar 60 dan $65 \%$. Hal ini disebabkan pengaruh bahan pembasa terutama basa anorganik memberikan kontribusi terhadap kekerasan. Kemudian untuk semua parameter hasil pengujian dalam penelitian ini, vulkanisat yang mengandung bahan pelunak lindi hitam tanpa perlakuan penambahan bahan pembasa dengan kadar padatan sebesar $60 \%$ memiliki kinerja yang setara dengan vulkanisat yang mengandung bahan pelunak kontrol (minarex). Disamping itu, adanya bahan pelunak dari lindi hitam juga diduga memberikan fungsi tambahan sebagai bahan anti oksidasi karena di dalam bahan lindi hitam mengandung komponen bahan lignin yang di dalam struktur molekulnya banyak terdapat gugus fenolik tersubtitusi.

\section{KESIMPULAN DAN SARAN}

Hasil pengujian spektrometri FTIR menunjukkan bahwa lindi hitam mengandung senyawa aromatik dan mengandung gugus fungsi $-\mathrm{OH},-\mathrm{C}-\mathrm{O}$, dan $-\mathrm{C}=\mathrm{O}$. Melalui proses perlakuan penguapan bahan mudah menguap pada lindi hitam dapat dihasilkan lindi hitam yang memiliki sifat sebagai bahan pelunak pada barang jadi karet.

Kompon karet yang mengandung bahan pelunak lindi hitam tanpa perlakuan ataupun dengan perlakukan penambahan bahan pembasa $\mathrm{NH}_{4} \mathrm{OH}$ dan $\mathrm{NaOH}$ memiliki waktu masak optimum $\left(\mathrm{t}_{90}\right)$ dan waktu scorch $\left(\mathrm{ts}_{2}\right)$ yang lebih cepat dari pada kompon karet yang mengandung bahan pelunak kontrol (minarex) sifat-sifat fisika vulkanisat (kekerasan, kuat tarik, perpanjangan putus, ketahanan sobek, berat jenis, kepegasan pantul, ketahanan retak-lentur, ketahanan kikis, dan ketahanan ozon) yang mengandung bahan pelunak lindi hitam dengan perlakuan penambahan bahan pembasa ataupun tanpa perlakuan memiliki hasil yang hampir setara dengan sifat fisika vulkanisat yang mengandung bahan pelunak kontrol (minarex), bahkan untuk vulkanisat yang mengandung bahan pelunak lindi hitam tanpa perlakuan penambahan bahan pembasa dengan kadar padatan sebesar $60 \%$ memiliki kinerja yang 
setara dengan vulkanisat yang mengandung bahan pelunak kontrol (minarex).

\section{DAFTAR PUSTAKA}

Arizal, R. 1990. Pengaruh hasil analisa kimia bahan pelunak-minyak terhadap kompon dan vulkanisat karet. Pros. Lok. Processing Oil'90. Jakarta, 27-28 Februari. Pusat Pengendalian Mutu Petrokimia, 1-9.

Badan Pusat Statistik. 2010. Ekspor - Impor 2010. Badan Pusat Statistik, Jakarta.

Brunow, G. 1998. Oxidative coupling of phenols and the biosynthesis of lignin. In Lignin and Lignan Biosynthesis. www.pubs.acs.org diakses tanggal 1 Juli 2012.

Honggokusumo, S. dan N. Bahar. 1998. Penggunaan Lignin Termodifikasi Sebagai Bahan Pelunak Kompon Karet, Simposium Nasional Polimer II. Bogor, 8 Juli. Himpunan Polimer Indonesia, 178-184.

McCrady, E. 1991. The Nature of Lignin. Alkaline Paper Advokat 4 (4). WwW.cool.conservation-us.org. diakses tanggal 1 Juli 2012.
Rahman, M. and C.S. Brazer. 2004. The plasticizer market: an assessment of traditional plasticizers and research trends to meet new challenges. Progress in Polymer Science 29 : 12231248 .

Raju, P., V. Nandanan, and K.N. Kutty Sunil . 2007. A study on the use of castor oil as plasticizer in natural rubber compounds. Progress in Rubber, Plastics, and Recycling Technology 23 (3), 169-180.

Sjostrom, E. 1995. Kimia Kayu, Dasar-dasar dan Penggunaan Edisi Kedua. Diterjemahkan oleh Sastrohamidjojo, H. Terjemaahan dari : Wood Chemistry, Fundamentals and Application Second Edition. Gadjah Mada University Press, Yogyakarta.

Suseno, R.S. 1990, Memanfaatkan bahan pembantu produk dalam negeri untuk industri karet. Pro. Lok. Processing Oil'90. Jakarta 27-28 Februari. Pusat Pengendalian Mutu Petrokimia, 1-13.

Vanholme, R., B. Demedts, K. Morreel, J. Ralph, and W. Boerjan. 2010. Lignin biosynthesis and structure. Plant Physiology 153 (3), 895-905. 